\title{
DAMPAK PENDAMPINGAN TEKNOLOGI OLEH BPTP JAWA TENGAH PADA PEBIBITAN SAPI PO KEBUMEN
}

\author{
Dian Maharso Yuwono, Elly Kurniyati, dan Puji Lestari \\ Balai Pengkajian Teknologi Pertanian (BPTP) Jawa Tengah \\ Email: dianmy@yahoo.com
}

\begin{abstract}
One of the strategic programs in Indonesian Ministry of Agriculture is the acceleration on beef self-sufficiency (PSDS). The implementation of PSDS program was based on the consideration that local cattle just able to supply $70 \%$ of meat demand, while the lacks were fulfilled from import. In order to support PSDS program, Assessment Institute of Agricultural Technology (AIAT) Central Java has been doing the assistance through dissemination activities in 2010-2014. One of the focus of AIAT Central Java in PSDS assistance was the improvement of genetic properties and maintanance of $P O$ cattle in Kebumen. The aim of this study was to learn the impact of technology assistance on the development of PO cattle in Kebumen. The study was conducted in Kebumen on September - November 2015. This study used survey methods with the observed aspects comprises the involvement level of member group, the productivity of introduced technology, the increasement on economic level, and the satisfaction level of farmer group toward AIAT Central Java services. The results showed that the technology of cattle selection was applied consistently to obtain qualified beef cattle, while the management aspect that was related to feed, shed, and reproduction could afford an increasein production/ productivity. The impacts of technology accompaniment i.e. better health condition of the cattle, better calves quality, the weight of birth raised about 2-3 kg, the body weight increase about 1,5-5 kg/month, and shorten the duration of giving birth (from 15-17 months to 11-12 months). Economically, the introduction of sustainable selection technology have been increasing the price of $P O$ Kebumen cattles. The price of male cattles increased 30-50\% from previous price.
\end{abstract}

Keywords: impact, accompaniment, technology, PO Kebumen cattle.

\begin{abstract}
Abstrak : Salah satu program strategis Kementerian Pertanian adalah pendampingan pada Program Percepatan Pencapaian Swasembada Daging Sapi (P2SDS) yang kemudian ditambah dengan ternak kerbau sehingga menjadi PSDS/K. Dasar pelaksanaan program PSDS utamanya adalah kemampuan sapi lokal untuk mensuplai kebutuhan daging hanya $70 \%$, sedangkan sisanya dipenuhi dari impor. Dalam rangka mendukung PSDS, Balai Pengkajian Teknologi Pertanian (BPTP) Jawa Tengah telah melakukan pendampingan melalui kegiatan pengkajian/diseminasi sepenjang tahun 2010-2014.Salah satu yang menjadi fokus BPTP Jawa Tengah dalam pendampingan PSDS adalah perbaikan mutu genetik dan manajemen pemeliharaan sapi Peranakan Ongole (PO) di Kabupaten Kebumen.Tujuan dari penelitian ini adalah untuk mengetahui dampak pendampingan teknologi oleh BPTP Jawa Tengah pada pengembangan sapi PO di Kabupaten Kebumen. Penelitian dilaksanakan pada bulan September - Nopember 2015 di Kabupaten Kebumen dengan menggunakan metode survei, adapun aspek yang diteliti mencakup tingkat keterlibatan anggota kelompok ternak, capaian tingkat produktivitas dan ekonomi pada penerapan teknologi, teknologi yang diintroduksikan dan rekayasa kelembagaan yang digunakan oleh kelompok tani/penyuluh pada kegiatan penyuluhan, serta tingkat kepuasan anggota kelompok tani terhadap jasa pelayanan BPTP Jawa Tengah. Hasil survey
\end{abstract}


Dian Maharso Y., Elly Kurniyati, Dan Puji L. : Dampak Pendampingan Teknologi ...

menunjukkan introduksi seleksi ternak diterapkan secara berkelanjutan untuk mendapatkan bibit ternak sapi potong yang berkualitas, sedangkan aspek manajemen budidaya sapi potong yang menyangkut pakan, perkandangan,dan reproduksi telah memberikan manfaat bagi peningkatan produksi/produktivitas. Pendampingan teknologi berdampak pada kondisi kesehatan induk dan pedet semakin baik, induk mudah birahi, kualitas pedet semakin bagus, meningkatkan bobot lahir pedet sekitar 2$3 \mathrm{~kg}$, meningkatkan pertambahan bobot badan sekitar 1,5-5 kg/bulan, memperpendek jarak beranak dari 15 - 17 bulan menjadi 11-12 bulan.Dilihat dari aspek ekonomi, introduksi teknologi seleksi secara berkelanjutan telah meningkatkan harga sapi PO Kebumen. Secara umum harga pasar untuk pejantan unggul pada kategori umur yang sama meningkat 30-50\% dibandingkan dengan harga sebelumnya.

Kata kunci : dampak, pendampingan, teknologi, sapi PO Kebumen

\section{PENDAHULUAN}

Pemenuhan kebutuhan daging nasional sebagian besar dipasok dari daging unggas $(58,02 \%)$ dan daging sapi $(21,27 \%)$. Pemenuhan daging unggas berdasarkan proyeksi senjang produksi dan konsumsi kurun waktu 2006-2010 mengalami surplus (Bappenas, 2006), sehingga pemerintah belakangan ini cenderung memberikan perhatian yang khusus terhadap penyediaan kebutuhan daging sapi. Salah satuprogram strategis Kementerian Pertanianadalah pendampingan pada Program Percepatan Pencapaian Swasembada Daging Sapi (PSDS) yang kemudian ditambah dengan ternak kerbau sehingga menjadi PSDS/K. Dasar pelaksanaan program PSDS utamanya adalah kemampuan sapi lokal untuk mensuplai kebutuhan daging hanya $70 \%$, sedangkansisanya dipenuhi dari impor.Program PSDS menyangkut aspek penawaran daging sapi melalui upaya guna menjamin ketersediaan pangan hewani asal ternak berbasis sumberdaya domestik khususnya ternak sapi potong (Kementerian Pertanian, 2010).Menurut Kusriatmi (2013) beberapa motif yang mendorong penerapan strategi substitusi impor dalam pengembangan ternak/daging sapi potong adalah ketersediaan sumberdaya alam dan faktor produksi, potensi permintaan yang tinggi, dan penciptaan lapangan kerja di dalam negeri.

Program PSDS lebih ditekankan pada pembibitan sapi potong lokal dengan meningkatkan produktivitas dan reproduktivitasnya (Ditjen Peternakan, 2011). Sapi potong lokal adalah sapi potong asli Indonesia (sejak dahulu sudah ada di
Indonesia) dan sapi yang berasal dari luar Indonesia, tetapi sudah berkembang biak dan dibudidayakan lama sekali di Indonesia sehingga telah mempunyai ciri khas tertentu (Hardjosubroto, 1994). Sapi potong lokal merupakan salah satu sumberdaya genetik (SDG) yang mempunyai nilai ekonomis dan sosial budaya yang tinggi (Anonimus, 2005). Keberadaan sapi potong lokal di Indonesia sebagai salah satu komoditas usaha khas lingkungan perdesaan, merupakan bagian integral dari usaha pertanian masyarakat perdesaan, berfungsi sebagai sumber tenaga kerja pengolah lahan pertanian, sumber pupuk organik, sebagai hewan yang mempunyai nilai ekonomis dalam memanfaatkan biomas limbah pertanian, serta sebagai tabungan hidup.

Sumberdaya sapi lokal ditingkatkan kemampuannya untuk mengotimalkan kemampuan produksi dan produktivitas ternak lokal.Salah satu bangsa sapi potong lokal yang memegang peranan penting dalam penyediaan kebutuhan daging nasional sapi peranakan Ongole (PO).Sebagai pengaruh dari variasi geografis antar wilayah (iklim dan kondisi tanah) di Indonesia, akhirnya terbentuk populasi sapi potong lokal yang berbeda-beda karakteristiknya (Thohari, 2000).Diantara sapi PO yang dikembangkan peternak di berbagai wilayah, sapi PO Kebumen selama ini tergolong sapi potong yang memiliki berbagai keunggulan. Sapi PO Kebumen memiliki tubuh yang tinggi dan panjang dibandingkan sapi PO yang dibudidayakan di daerah pengembang lainnya (Aryogi dan Romjali, 2006). Tahun 2015 sapi PO Kebumen telah ditetapkan oleh Keputusan Menteri Pertanian sebagai Galur Sapi PO Kebumen (Disnak 
Keswan Prov. Jateng, 2015), dengan demikian secara yuridis formal bahwa Sapi PO Kebumen merupakan salah satu sumberdaya genetik yang potensial sepesifik yang dimiliki oleh Kabupaten Kebumen sebagai pusat pengembangan Sapi PO.

Pendampingan Balai Pengkajian Teknologi Pertanian (BPTP) Jawa Tengah pada program PSDS melalui kegiatan pengkajian dan diseminasi sepanjang tahun 20102015(Subiharta et al., 2012). Salah satu yang menjadi fokus BPTP Jawa Tengah dalam pendampingan PSDS adalah perbaikan mutu genetik dan manajemen pemeliharaan sapi Peranakan Ongole (PO) di Kabupaten Kebumen. Pendampingan BPTP Jawa Tengah pada pelaksanaan PSDS pada 20102014 di Kabupaten Kebumen meliputi : (1) Peningkatan kapasitas sumberdaya (SDM) peternak sapi potong terkait dengan manajemen budidaya ternak sapi potong sesuai dengan anjuran, melalui berbagai media diseminasi (temu lapang, pelatihan, VCD, buku petunjuk teknis, leaflet, brosur); (2) Seleksi ternak secara berkelanjutan, untuk mendapatkan bibit ternak sapi potong yang berkualitas; (3) Pengkajian terkait dengan manajemen sapi potong (pakan, perkandangan, reproduksi), dan; (4) Pembinaan kelembagaan pusat perbibitan sapi potong di perdesaan (village breeding center). Sehubungan hal tersebut telah dilakukan penelitian untuk mengetahui dampak pendampingan teknologi olehBPTP Jawa Tengah pada pengembangan sapi PO di Kabupaten Kebumen.

\section{METODOLOGI}

Penelitian dilaksanakan pada bulan September - Nopember 2015 dengan pendekatan survey, data primer yang dikumpulkan melalui survei menggunakan kuesioner terstruktur dan kuesioner arahan, survey dilakukan untuk mendapatkan informasi mengenai dampak pendampingan BPTP Jawa Tengah pada program PSDS/K sepanjang tahun 2010-2014 khususnya di Kabupaten Kebumen, menyangkut : (1) Tingkat keterlibatan anggota kelompok ternak dalam kegiatan pendampingan PSDS/K oleh BPTP Jawa Tengah; (2) Capaian tingkat produktivitas dan ekonomi pada penerapan teknologi; (3) Teknologi yang diintroduksikan dan rekayasa kelembagaan oleh BPTP Jawa Tengah pada pendampingan PSDS yang digunakan oleh kelompok tani/penyuluh pada kegiatan penyuluhan; (4) Mengetahui dampak kemitraan dalam kegiatan pendampingan PSDS oleh BPTP Jawa Tengah, dan; (5) Tingkat kepuasan anggota kelompok tani terhadap jasa pelayanan BPTP Jawa Tengah. Studi dampak tersebut mengacu pada Petunjuk Tenis Pengukuran Keberhasilan P3TIP/FEATI (BBP2TP, 2011).

Survey dilaksanakandi : 1. Kelompok Tani Ternak "Gelora Tani”, Desa Tanggulangin, Kecamatan Klirong, Kabupaten Kebumen, dan 2. Kelompok Tani Ternak Suro Madu Desa Karangrejo, Kecamatan Petanahan, Kabupaten Kebumen. Responden survey adalah pengurus kelompok, penyuluh, inseminator, petugas peternakan, peternak pelaksana dan non pelaksana kegiatan pengkajian yang dilaksanakan BPTP Jawa Tengah tahun 20102014, adapun jumlah responden sekitar 25-30 orang/lokasi. Data hasil survey dampak pendampingan $\mathrm{PSDS} / \mathrm{K}$ ditabulasi dan dianalisis secara deskriptif kualitatif dan kuantitatif dengan menganalisis keseluruhan variabel yang telah diidentifikasi.

\section{HASIL DAN PEMBAHASAN}

\section{Identitas Peternak}

Tabel 1 menunjukkan identitas peternak di lokasi penelitian.Sebagian besar peternak di kedua kabupaten berada pada usia produktif, yakni 30-60 tahun, hanya sebagian kecil yang tergolong usia lanjut. Apabila mengacu padaWiriatmadja (1978), responden didominasi oleh pengetrap dini hingga pengetrap akhir, yakni berumur 30-50 tahun.Meskipun dalam kenyataannya tidak selalu berlaku demikian, namun setidaknya faktor umur perlu diperhatian sebagai bahan pertimbangan dalam mengintroduksikan suatu inovasi kepada petani.Kualitas sumberdaya peternak dapat dikatakan masih rendah, karena sebagian besar memiliki tingkat pendidikan SD atau kurang. Kondisi ini lebih rendah dibandingkan dengan hasil Sensus Pertanian tahun 2003 (BPS, 2004) yang mendapatkan bahwa untuk petani di Pulau Jawa yang berpendidikan SD ke bawah sejumlah $54,31 \%$. Salah satu penyebab rendahnya tingkat pendidikan petani responden adalah karena tenaga kerja daerah pedesaan yang berpendidikan relatif tinggi lebih 
Dian Maharso Y., Elly Kurniyati, Dan Puji L. : Dampak Pendampingan Teknologi ...

terdorong untuk melakukan migrasi, dengan harapan peluang mereka untuk mendapatkan pekerjaan dengan upah lebih tinggi di perkotaan lebih besar. Sebagian besar responden menjadikan budidaya ternak sapi potong sebagai mata pencaharian utama.Pengalaman beternak sapi potong sebagian besar peternak di Desa Karangrejo dan Tanggulangin Kabupaten Kebumencukup lama yakni 10 tahun ke atas.Tujuan produksi peternak baik di Kabupaten Kebumenadalah perbibitan, selebihnya bertujuan penggemukan maupun kombinasi antara perbibitan dan penggemukan.

Keterlibatan Anggota Kelompok Ternak pada Kegiatan Pengkajian BPTP Jawa Tengah

Indikator keterlibatan/partisipasi anggota kelompok tani diperoleh dengan menghitung persentase anggota yang terlibat aktif dalam kegiatan pendampingan BPTP Jawa Tengah pada pelaksanaan PSDS 2010-2014 di Kabupaten Kebumen (Tabel 2).

Tabel 1.Identitas peternak di lokasi penelitian

\begin{tabular}{lcc}
\hline \multirow{3}{*}{ No Uraian } & \multicolumn{2}{c}{ Lokasi } \\
\cline { 2 - 4 } & $\begin{array}{c}\text { Desa Karangrejo, Kec. } \\
\text { Petanahan }\end{array}$ & $\begin{array}{c}\text { Desa Tanggulangin, Kec. } \\
\text { Klirong }\end{array}$ \\
\hline
\end{tabular}

1. Umur

- $\quad<30-40$ tahun

41,18

23,53

- $41-50$ tahun

- $51-60$ tahun

- >60 tahun

2. Pendidikan formal

- SD

- SMP

- $\quad$ SLTA

- Diploma

- PT

3. Pekerjaan utama

- Petani

11,76

13,33

- Peternak

- Dagang

- Buruh

- Perangkatdesa

- Lainnya

6. Pengalaman beternak sapi

- $<10$ tahun

17,65

16,67

- 10-20 tahun

47,05

46,67

- 21-30 tahun

17,65

13,33

- $>=31$ tahun

17,65

7. Tujuan usaha

- Perbibitan

- Penggemukan

- Perbibitan dan

17,65

20,00

Sumber : data primer, 2015 
Sepanjang tahun tersebut telah dilakukan kegiatan uji coba/percontohan: 1. Seleksi ternak secara berkelanjutan, untuk mendapatkan bibit ternak sapi potong yang berkualitas; 2. Pengkajian terkait dengan manajemen sapi potong (pakan, perkandangan, reproduksi). Dari 4 lokasi survey, responden pelaksana ujicoba BPTP Jawa Tengah persentase paling tinggi adalah padaKelompok Tani Ternak "Gelora Tani” Desa Tanggulangin, Kecamatan Klirong, Kabupaten Kebumen, ini disebabkan secara berkelanjutan melakukan kegiatan pengkajian secara berkelanjutan sepanjang tahun 2010 hingga 2014. Meskipun responden survey tidak seluruhnya sebagai peternak pelaksana kegiatan pengkajian, namun sebagian besar mengetahui kalau terdapat pengkajian di kelompok mereka.Hal ini karena setiap pertemuan kelompok selalu disampaikan kegiatan BPTP Jawa Tengah oleh pengurus kelompok maupun petugas.

Tabel 2. Keterlibatan peternak dalam kegiatan pengkajian BPTP Jateng

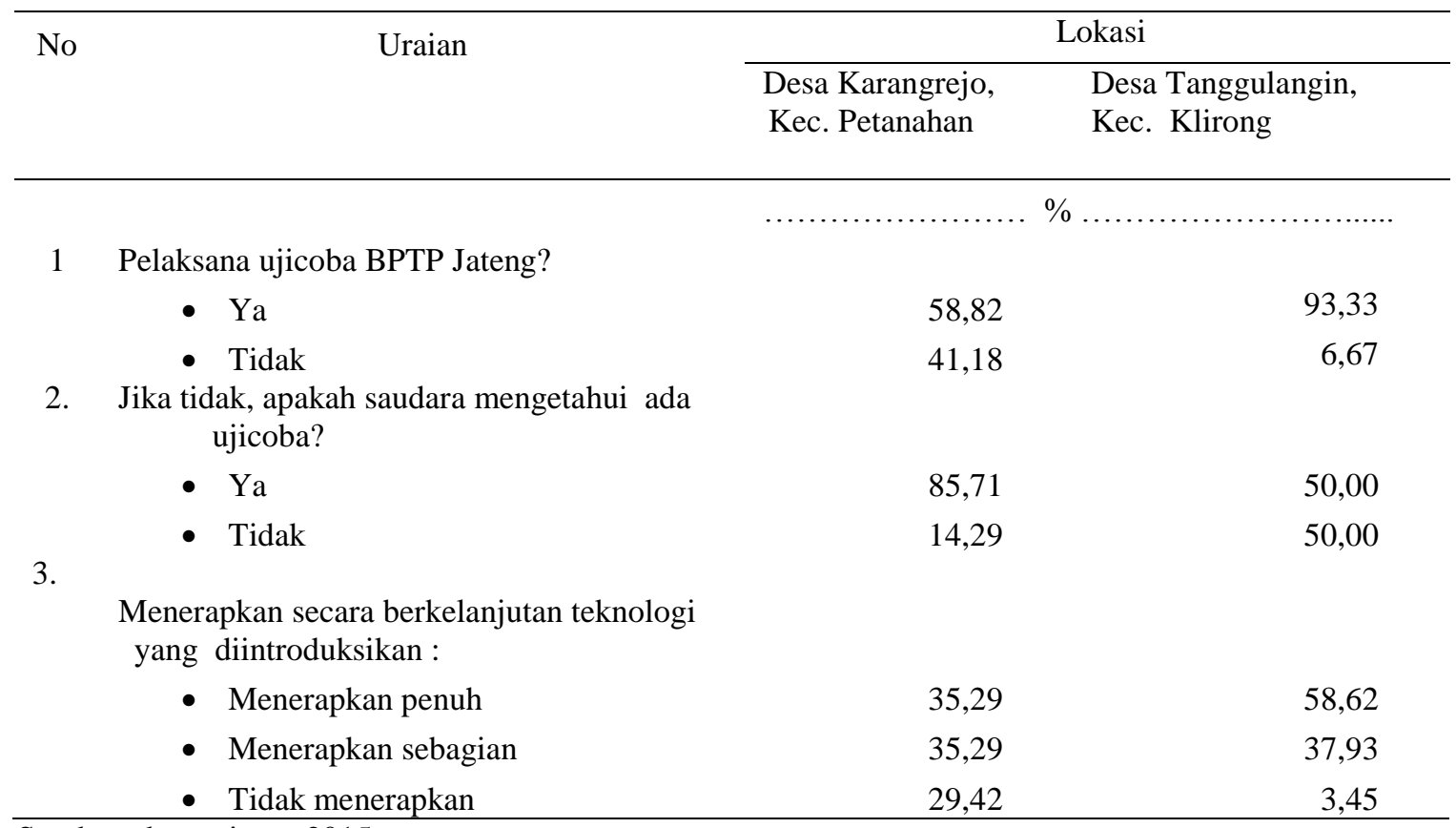

Sumber: data primer, 2015

Tabel 3. Dampak penerapan teknologi terhadap produktivitas di Kabupaten Kebumen

\begin{tabular}{llll}
\hline No. & \multicolumn{1}{c}{ Uraian } & \multicolumn{1}{c}{ Sebelum } & \multicolumn{1}{c}{ Setelah } \\
\hline 1. & Kondisi kesehatan induk & Kurang sehat/sehat & Lebih sehat \\
2. & Bobot lahir pedet & Kurang/biasa & Naik 2 $-3 \mathrm{~kg}$ \\
3. & Kondisi kesehatan pedet & Kurang sehat/sehat & Lebih sehat \\
4. & Kualitas pedet & Kurang/biasa & Lebih bagus \\
5. & Jarak beranak & $15-20$ bln & $11-12$ bulan \\
6. & Pertambahan bobot badan & Biasa & Naik 1,5-5 kg/bln \\
7. & Masa birahi & Sulit/lambat & Mudah/Cepat \\
\hline
\end{tabular}

Sumber : data primer, 2015 
Dian Maharso Y., Elly Kurniyati, Dan Puji L. : Dampak Pendampingan Teknologi ...

Tabel 4. Gambaran harga sapi PO berdasar umut dan status ternak di Kabupaten Kebumen

\begin{tabular}{llrr}
\hline Status/umur sapi PO & Kualitas sapi & \multicolumn{2}{c}{ Harga (juta Rp.) } \\
\cline { 3 - 4 } Pedet umur 4-5 bulan & Grade 1 & 13 & Betina \\
& Grade 2 & 10 & $10-11$ \\
& Grade 3 & 8 & $8-9$ \\
& Non klas & 6 & 6 \\
Pejantan/pemacek & Grade 1 & 33 & $4-4,5$ \\
& Grade 2-3 & 14 & - \\
\hline
\end{tabular}

Sumber: data primer, 2015

Dampak Penerapan Teknologi terhadap
Peningkatan Produktivitas dan Ekonomi

Introduksi seleksi ternak secara berkelanjutan, untuk mendapatkan bibit ternak sapi potong yang berkualitas; serta manajemen sapi potong yang menyangkut pakan, perkandangan, dan reproduksi memberikan manfaat bagi peningkatan produksi/ produktivitas. Kondisi kesehatan induk dan pedet semakin baik, induk mudah birahi, kualitas pedet semakin bagus, meningkatkan bobot lahir pedet sekitar 2-3 kg, meningkatkan pertambahan bobot badan sekitar 1,5-5 kg/bulan, memperpendek jarak beranak dari 15 - 17 bulan menjadi 11-12 bulan (Tabel $3)$.

Dilihat dari aspek ekonomi, introduksi teknologi seleksi secara berkelanjutan telah meningkatkan kualitas sapi PO, khususnya di Kabupaten Kebumen lebih lama mendapatkan pendampingan dari BPTP Jawa Tengah.Secara umum harga pasar untuk pejantan unggul pada kategori umur yang sama meningkat 30-50 \% dibandingkan dengan harga sebelumnya. Kondisi ini tentunya merupakan rangsangan bagi peternak untuk lebih meningkatkan usahanya terlebih inovasi dalam perbaikan sistem perbibitan ini tidak menambah beban biaya operasional peternak sehingga dirasakan keuntungannya.Di wilayah pengembangan sapi PO berkualitas di Kebumen terdapat 3 kualitas (grade). Penentuan grade berdasar kesesuaian sapi PO dengan standar sapi PO Kebumen yang telah ditetapkan tim.SapiPO digolongkan grade 1 apabila $90-100 \%$ sesuai dengan standar, grade $280-90 \%$ dari standar, sedangkan grade 3 Gambaran harga sapi PO berkualitas seperti tercantum pada Tabel 4.

Keberhasilan pengembangan usaha perbibitan sapi PO Kebumen juga berdampak terhadap pengembangan usahatani.Dalam beberapa tahun terakhir ini telah tumbuh dengan cepat usahatani hortikultura (pepaya, pisang dan sayuran) dimana kondisi tersebut ternyata juga sejalan dengan keberhasilan pengembangan usaha perbibitan sapi PO Kebumen.Intensitas penanaman di lahan kering Kebumen Selatan menjadi meningkat dengan berbagai tanaman komersial sebagai akibat melimpahnya pupuk kandang.Perluasan tanaman rumput pakan, pepaya California, pisang dan sayuran semusim secara intensif diusahakan untuk tujuan komersial.Selama ini keberadaan tanaman tersebut sudah ada namun hanya sebetas untuk memenuhi keperluan sendiri.Bahkan saat ini juga berkembang cabang usaha baru berupa perdagangan hijaun (rumput) diberbagai tempat di wilayah pengembangan (Gambar 3).Cabang usaha lainnya yang ikut berkembang adalah mulai diperjualbelikannya pupuk kandang. Kedua cabang usaha tersebut selama ini belum memiliki nilai bisnis sehingga belum ada pasarnya.

\section{Dampak Kemitraan}

Keberhasilan pengembangan sistem perbibitan sapi PO Kebumen telah menciptakan kelembagaan baru dalam banyak aspek misalnya permodalan, jaminan resiko, fasilitator peternak baik formal maupun non formal.(Tabel 4).Pada aspek kelembagaan, perkembangan skala (scaling up) perbaikan bibit sapi PO Kebumen diwadahi oleh Asosiasi Kelompok Perbibitan Sapi PO Kebumen "Aspokeb" yang didirikan pada 13 Nopember 2013 dengan Akte Notaris. Asosiasi "Aspokeb" mengkonsolidasikan kegiatan perbibitan sapi PO yang dilakukan peternak di seluruh wilayah Kabupaten Kebumen.Pengurus asosiasi dipilih dari 29 kelompok ternak yang ada di kabupaten. Munculnya asosiasi difasilitasi dari 
Dian Maharso Y., Elly Kurniyati, Dan Puji L. : Dampak Pendampingan Teknologi ...

Tabel 5. Perkembangan kemitraan usaha perbaikan kualitas Sapi PO Kebumen

\begin{tabular}{|c|c|c|c|c|}
\hline & Nama Mitra & Bentuk Kemitraan & Peride Mitra & Volume \\
\hline 1. & $\begin{array}{l}\text { Investor } \\
\text { Perseorangan }\end{array}$ & $\begin{array}{l}\text { Penanaman modal usaha } \\
\text { perbibitan }\end{array}$ & Mulai 2014- sekarang & $\begin{array}{l}>\mathrm{Rp} 200.000 .000(15 \\
\text { ekor }) / 18 \text { bulan }\end{array}$ \\
\hline 2. & Asuransi Raya & Jaminan Kematian Ternak & Mulai 2014- sekarang & 108 ekor \\
\hline 3. & Asosiasi Peternak & $\begin{array}{l}\text { Advokasi kepentingan } \\
\text { peternak }\end{array}$ & Mulai 2013-sekarang & 29 kelompok tani \\
\hline 4. & Kepolisian & $\begin{array}{l}\text { Penyidikan terkait kasus } \\
\text { kehilangan sapi }\end{array}$ & Sampai sekarang & \\
\hline 5. & Balai Keswan & $\begin{array}{l}\text { Penyidikan terkait kasus } \\
\text { penyakit/kematian sapi }\end{array}$ & Sampai sekarang & \\
\hline 6. & BPTP Jateng & $\begin{array}{l}\text { Sumber rujukan dan } \\
\text { pendamping teknologi } \\
\text { perbibitan. }\end{array}$ & Sejak 2010-sekarang & $\begin{array}{l}29 \text { kelompok tani } \\
\text { (seluruh komunitas } \\
\text { peternak Sapi PO } \\
\text { Kebumen) }\end{array}$ \\
\hline 7. & $\begin{array}{l}\text { Dinas Koperasi } \\
\text { dan UMKM }\end{array}$ & Pembinaan usaha & Sejak 2013- sekarang & \\
\hline
\end{tabular}

Sumber: data primer, 2015

dinas setempat berdasarkan usulan dari bawah yang membutuhkan keberadaan asosiasi. Kegiatan usaha asosiasi meliputi penyediaan pakan, pupuk, perdagangan umum, pemasaran sapi.Peran kelompok dan asosiasi menyangkut penjualan, asuransi, pengukuran ternak dalam rangka seleksi (penimbangan, tinggi gumba dll), setiap kelahiran ditimbang.Pemasaran yang sudah ditangani asosiasi adalah pemenuhan pesanan dari BPTU Sembawa mengenai bibit $\mathrm{PO}$ grade 2-3 sejumlah 28 ekor, dan 5 ekor induk dan 1 ekor pejantan dari grade 2-3 dari fihak swasta.

Dengan tersebarnya informasi tentang prospek keunggulan sapi PO Kebumen telah menumbuhkan minat investor untuk menanamkan modalnya pada usaha perbibitan.Dalam tahap rintisan ini sudah tertanam modal >Rp 200 juta untuk 15 ekor sapi pejantan. Investor bekerja sama dengan peternak di lokasi pengembangan untuk menghasilkan produk berupa pejantan unggul sumber bibit. Untuk mendapatkan keragaan pertumbuhan pejantan dengan tingkat harga yang optimal periode usaha ditetapkan selama 18 bulan. Usaha tersebut nampaknya cukup menguntungkan sehingga saat ini juga sudah muncul penwaran kontrak baru dengan investor lainnya.
Pejantan unggul PO Kebumen yang bernilai ekonomi tinggi selama pemeliharaan tentunya juga menghadapi resiko ketidakpastian dari kejadian yang tidak diinginkan. Kesadaran terhadap upaya menghindari adanya resiko kerugian teruma dari kasus kematian menjadi peluang masuknya lembaga penjaminan resiko. Saat ini telah hadir salah satu perusahaan yang bergerak pada aspek jaminan kematian ternak yaitu Asuransi Raya.Perusahaan ini menawarkan perlindungan resiko kerugian peternak akibat kematian ternak sesuai polis asuransi yang disepakati.Sejak beroperasi pada awal 2014 hingga saat ini jumlah pejantan yang diasuransikan berjumlah 108 ekor. Premi yang dibayar peternak sebesar $2 \%$ dari harga taksiran yang disetujui. Jumlah peternak yang akan mengikuti asuransi nampaknya terus bertambah sebagai peningkatan kesadaran akan pentingnya perlindungan usaha.

Dukungan terhadap keberhasilan pengembangan sistem perbibitan sapi PO Kebumen tidak terlepas dari Asosiasi Peternak.Peran asosiasi ini adalah sebagai advokasi kepentingan peternak dan fasilitator serta mediator peternak dengak pihak pemangku kepentingan. Secara teknis asosiasi ini juga berperan dalam registrasi pejantan pilihan, pendampingan teknologi, tim otoritas 
pembuat SKLB dan tim penandatangan MOU dari 7 instansi pengatur sistem perbibitan sapi PO Kebumen. Saat ini asosiasi peternak melayani anggota sebanyak 29 kelompok peternak yang tersebar di wilayah pengembangan usaha perbibitan sapi PO Kebumen.Pelaksanaan konsep sistem perbibitan sapi PO Kebumen hingga saat ini masih merujuk pada saran masukan yang disusun oleh BPTP Jawa Tengah terutama kegiatan dan perencanaan yang terkait dengan perbibibitan sapi . Sementara itu keterlibatan pihak Kepolisian dan Balai Kesehatan Hewan secara teknis maupun administratif keterlibatannya semakin diperlukan terlebih dengan semakin berkembangnya sistem perlindungan jaminan melalui asuransiternak.Berdasarkan promosi dari asosiasi, Tahun 2014 mulai ada investor (penggaduh) untuk pembibitan anak, dengan pembagian $40 \%$ investor : $60 \%$ penggaduh.
Untuk porsi investor : 10\% kelompok, 30\% investor.

Teknologi yang Diintroduksikan untuk Kegiatan Penyuluhan

Teknologi yang diintroduksikan oleh BPTP Jawa Tengah disampaikan melalui berbagai media, baik dalam bentuk ujicoba/pengkajian, temu lapang, temu tugas, lokakarya, workshop, leaflet/VCD, dan pelatihan. Keseluruhan bentuk kegiatan pendampingan PSDS yang dilaksanakan BPTP Jawa Tengah menjadi materi penyuluhan yang dilakukan oleh penyuluh maupun kelompok tani (Tabel 6).

\section{Tingkat Kepuasan Anggota Kelompok Ternak}

Kepuasan kelompok ternak yang menerima jasa layanan teknologi oleh BPTP Jawa Tengah pada pendampingan PSDS di Kabupaten Kebumen seperti tercantum pada Tabel 7.

Tabel 6. Teknologi yang diintroduksikan BPTP Jawa Tengah yang diterapkan oleh penyuluh/kelompok ternak dalam kegiatan penyuluhan

\begin{tabular}{cll}
\hline No & \multicolumn{1}{c}{ Teknologi yang diintroduksikan } & Teknologi disuluhkan pada petani lain \\
\hline 1. & Pemberian pakan tambahan & Disuluhkan \\
2. & Pembuatan amoniasi jerami & Disuluhkan \\
3. & Penyapihan dini & Disuluhkan \\
4. & Pemberian hijauan pakan griricidae & Disuluhkan \\
5. & Pembuatan mol & Disuluhkan \\
6. & Pengolahan pupuk organik & Disuluhkan \\
7. & Cara rekording ternak & Disuluhkan \\
8. & Cara pengukuran dan penimbangan ternak & Disuluhkan \\
9. & Kelembagaan kelompok tani & Disuluhkan \\
\hline
\end{tabular}

Sumber: data primer, 2015

Tabel 7. Kepuasan petani terhadap pelayanan jasa BPTP Jawa Tengah

\begin{tabular}{llcc}
\hline & Indikator & Demplot/Uji & Pelatihan \\
\hline 1. & Tingkat kebaruan teknologi & Banyak & Banyak \\
2. & Tingkat kesesuaian teknologi dengan & Sesuai & Sangat Sesuai \\
& kebutuhan petani & & Puas \\
3. & Tingkat kepuasan terhadap muatan & Puas & \\
& materi & & Sama saja \\
4. & Tingkat kerumitan materi teknologi & Sama saja & Tinggi \\
5. & Tingkat manfaat teknologi baru & Tinggi & Tinggi \\
6. & KesesuaiandenganBudayaLokal & Tinggi & \\
\hline
\end{tabular}

Sumber : data primer, 2015 
Tingkat kepuasan terhadap pelayanan jasa BPTP Jawa Tengah, baik yang disampaikan dalam bentuk media informasi (leaflet, petunjuk teknis, compact disk/CD), pelatihan, maupun pelaksanaan percontohan/demplot/uji coba.Secara umum peternak menyampaikan bahwa teknologi yang disampaikan melalui berbagai media sesuai dengan kebutuhan peternak dan peternak puas-sangat puas dengan jasa layanan teknologi. Dari aspek penerapannya, teknologi yang disampaikan mudah untuk diterapkan dan bermanfaat bagi peningkatan produksi dan pendapatan petani.

\section{KESIMPULAN}

1. Hasil survey menunjukkan keterlibatan anggota kelompok tani pada pelaksanaan pendampingan teknologi oleh BPTP Jawa Tengah pada PSDS/K persentase paling tinggi adalah pada Kelompok Tani Ternak "Gelora Tani" Desa Tanggulangin, Kecamatan Klirong, Kabupaten Kebumen, ini disebabkan secara berkelanjutan melakukan kegiatan pengkajian secara berkelanjutan sepanjang tahun 2010 hingga 2014. Meskipun responden survey tidak seluruhnya sebagai peternak pelaksana kegiatan pengkajian, namun sebagian besar mengetahui kalau terdapat pengkajian di kelompok mereka. Hal ini karena setiap pertemuan kelompok selalu disampaikan kegiatan BPTP Jawa Tengah oleh pengurus kelompok maupun petugas.

2. Introduksi seleksi ternak secara berkelanjutan, untuk mendapatkan bibit ternak sapi potong yang berkualitas; serta manajemen sapi potong yang menyangkut pakan, perkandangan, dan reproduksi memberikan manfaat bagi peningkatan produksi/produktivitas. Kondisi kesehatan induk dan pedet semakin baik, induk mudah birahi, kualitas pedet semakin bagus, meningkatkan bobot lahir pedet sekitar 2-3 kg, meningkatkan pertambahan bobot badan sekitar 1,5-5 kg/bulan, memperpendek jarak beranak dari $15-17$ bulan menjadi 11-12 bulan.

3. Dilihat dari aspek ekonomi, introduksi teknologi seleksi secara berkelanjutan telah meningkatkan kualitas sapi PO, khususnya di Kabupaten Kebumen lebih lama mendapatkan pendampingan dari BPTP Jawa Tengah. Secara umum harga pasar untuk pejantan unggul pada kategori umur yang sama meningkat 30-50 \% dibandingkan dengan harga sebelumnya.

4. Keberhasilan pengembangan usaha perbibitan sapi PO Kebumen juga berdampak terhadap pengembangan usahatani. Dalam beberapa tahun terakhir ini telah tumbuh dengan cepat usahatani hortikultura (pepaya, pisang dan sayuran) dimana kondisi tersebut ternyata juga sejalan dengan keberhasilan pengembangan usaha perbibitan sapi PO Kebumen. Intensitas penanaman di lahan kering Kebumen Selatan menjadi meningkat dengan berbagai tanaman komersial sebagai akibat melimpahnya pupuk kandang. Perluasan tanaman rumput pakan, pepaya California, pisang dan sayuran semusim secara intensif diusahakan untuk tujuan komersial.

5. Kegiatan perbaikan kualitas sapi PO Kebumen mendorong munculnya kemitraan dengan berbagai fihak, yakni investor perorangan, asuransi, kepolisian, asosiasi ternak, dinas koperasi dan UMKM, balai kesehatan hewan, dan BPTP Jawa Tengah.

6. Teknologi yang diintroduksikan oleh BPTP Jawa Tengah disampaikan melalui berbagai media menjadi materi penyuluhan, baik yang dilakukan kelompok ternak maupun penyuluh pertanian. Selain itu, peternak puas terhadap jasa layanan teknologi oleh BPTP Jawa Tengah.

\section{DAFTAR PUSTAKA}

Anonimous. 2005. Sumberdaya Hayati Ternak Lokal Jawa Tengah. Dinas Peternakan Propinsi Jawa Tengah dengan Balai Pengkajian Teknolog Pertanian Jawa Tengah. Semarang.

Aryogi dan Romjali E. 2006.Potensi, pemanfaatan, dan kendala pengembangan Sapi Potong Lokal sebagai kekayaan plasma nutfah Indonesia.Lokakarya Nasional Pengelolaan dan Perlindungan Sumber Daya Genetik di Indonesia. Bogor (Indones). Pusat Penelitian dan 
Pengembangan Peternakan. Bogor. hlm. 151-167.

Astuti M. 2004. Potensi dan keragaman sumberdaya genetik sapi Peranakan Ongole (PO).Wartazoa.Pusat Penelitian dan Pengembangan Peternakan. Bogor. 14:98-106.

Bappenas. 2013. Rencana Pembangunan Jangka Menengah Nasional (RPJM) Bidang Pangan dan Pertanian 20152019. Jakarta(ID): Direktorat Pangan dan Pertanian Badan Perencanaan dan Pembangunan Nasional. Jakarta.

BBP2TP. 2011. Petunjuk Tenis Pengukuran Keberhasilan P3TIP/FEATI. Balai Besar Pengkajian dan Pengembangan Teknologi Pertanian - Badan Penelitian dan Pengembangan Pertanian. Bogor.

Dinas Peternakan dan Keswan Prov. Jateng. 2015. Menteri Pertanian RI Tetapkan Galur Sapi PO Kebumen.http://pertanian.go.id/dinakkes wan_jateng/berita-menteri-pertanian-ritetapkan-galur-sapi-po-kebumen-.html

Ditjen Peternakan. 2011. Buku Statistik Peternakan dan Kesehatan Hewan Tahun 2011.Direktorat Jenderal Peternakan dan Kesehatan Hewan, Kementerian Pertanian RI. Jakarta.
Hardjosubroto, W. 1994. Aplikasi Pemuliabiakan Ternak di Lapangan. PT. Gramedia Widiasarana Indonesia. Jakarta.

Kementerian Pertanian. 2010. Peraturan Menteri Pertanian Nomor : 19 Tahun 2010 Tentang Pedoman Umum Program Swasembada Daging Sapi 2014. Jakarta (ID): Departemen Pertanian. Jakarta.

Kusriatmi.2014. Dampak Kebijakan Swasembada Daging Sapi terhadap Kinerja Ekonomi Subsektor Peternakan di Indonesia [disertasi]. Bogor (ID): Institut Pertanian Bogor. Bogor.

Subiharta, Muryanto, B. Utomo, Ernawati, R.N. Hayati, P. Sudrajad, I. Musawati, Suharno. 2012. Pendampingan PSDS melalui Inovasi Teknologi dan Kelembagaan. Laporan Kegiatan. BPTP Jawa Tengah.Ungaran.

Thohari, M. 2000. Pemanfaatan Plasma Nutfah Ternak Lokal dalam Sistem Usaha Tani Terintegrasi.Bahan Ajar Pelatihan Revitalisasi Keterpaduan Usaha Ternak dalam Sistem Usaha Tani.Bogor dan Surakarta, 20 Februari - 8 Maret 2000. Puslitbang Peternakan. Bogor.

Wiriatmadja, S. 1978. Pokok-Pokok Penyuluhan Pertanian. CV Yasagua. Jakarta. 